\title{
Illusory Facets of Sport: The Case of the Duke University Basketball Team
}

Authors' contribution:

A) conception and design of the study

B) acquisition of data

C) analysis and interpretation of data

D) manuscript preparation

E) obtaining funding

\author{
Łukasz Muniowski ${ }^{1 \mathrm{~B}, \mathrm{C}, \mathrm{E}}$, Tomasz Jacheć2 ${ }^{\mathrm{A}, \mathrm{D}, \mathrm{E}}$ \\ ${ }^{1}$ University of Warsaw, Poland \\ ${ }^{2}$ University of Warmia and Mazury, Olsztyn, Poland
}

ABSTRACT

In the society of the spectacle, illusion is an omnipresent phenomenon. It is used to distract the masses from issues crucial to their existence and to support a system of oppression. However, there is also a "lighter" side of illusion: it creates celebrities and helps sell products (films, music albums, sneakers, etc.). While the connotation is that spectacle uses illusion in order to present the ordinary or negative as extraordinary and positive (e.g., promiscuous athletes talking about family values), it is also possible for a reverse illusory process to take place, resulting in the regular being presented as irregular (e.g., a physical player presented as "aggressive", such as Kermit Washington). Unlike the deliberate use of illusion by the architects of the spectacle, this reverse process happens spontaneously.

This spontaneously generated illusion is especially evident in the world of sports. In this study, we focus on the Duke basketball team during the Mike Krzyzewski era. Since the early 1990s, Duke's basketball team has been considered a team of unathletic, clean-cut, and well-off individuals. As these qualities are stereotypically associated with white players or "white America" in general, Duke was categorized as a white, privileged team, with its African American players being perceived as tokens or "Uncle-Toms." We are not calling these illusions - at least not yet - as the validity of that opinion needs to be measured first. Before making our definite claim, we will analyze Duke's history during the era of Krzyzewski in order to determine whether the common perception regarding the roster (mostly white and privileged) is true or just an illusion. Our aim is to present why both the hate and reverence of the Duke University basketball team are caused by various illusions concerning the team in particular and academic sports in general.

KEYWORDS

spectacle, sports, iIllusions, values, succes, race, class

\section{Introduction}

In Why Sports Morally Matter, William J. Morgan makes a personal and nostalgic observation that during his youth, unorganized, unprofessional sports "frequently played a formative role in constituting both (...) sense of self and (...) sense of community" (2006, p. 23). Morgan underlines the importance of pick-up games, as they were and are a welcome departure from the adult world, which he understands as narcissistic and commodified. Once the market becomes involved in sports, various factors need to be taken into account before the actual game can begin. Tickets, arenas, sponsorships, and TV deals are just some of the components of the phenomenon known as professional sports that detract from, rather than contribute to, the events on the court or field. According to Morgan, "sports are treated more so as means than ends, as pursuits with a value to be instrumentally calculated as any other commodity: by the money they fetch," and "this is why professional sports have become more and more like the rest of life" (2006, p. 26). The pursuit of individual goals, which, according to the author, permeates modern society, should be excluded from sports in favor of 
team and communal goals. However, this is not totally possible, as on the professional level, sports are no longer understood as "play," defined by Bekoff as "(...) that behavior which is performed during social interactions in which there is a decrease in social distance between the interactants, and no evidence of social investigation or of agonistic [offensive or defensive] or passive-submissive behaviors on the part of the members of a dyad [triad, etc.] (...)" (Blanchard 1995, pp. 582-584).

The distinction between the two was made by Henri Lefebvre in The Critique of Everyday Life. Following the French philosopher's reasoning, Morgan's expectations concerning sports are typically bourgeois, as he expects sports - classified by Lefebvre as a leisure activity - to be an exception to the everyday. Lefebvre writes that "leisure must break with the everyday (...) not only as far as work is concerned, but also for day-to-day family life" (2014, p. 55). Simultaneously, Morgan expects sports to influence the everyday, as they should inspire a morality in their participants that will go beyond the field or court. Lefebvre focuses rather on the fact that sports are supposed to provide "a compensation for everyday life" (2014, p. 58). The need for such compensation is connected with the figure of the supporter, who is an active participant of a sporting event without being an active performer.

The shift from being an active performer in sports (play) to a spectator (an active participant) exposes the individual to the illusory spectacle that he or she may believe him or herself to be an active part of.

With his or her team emerging successful, the spectator is supposed to feel good not only about the team, but most of all about himself or herself, as if the success would not have been possible without him or her. In a way, sports are supposed to instill meaning in the otherwise meaningless life of a regular citizen. According to the Marxist thought exhibited by Lefebvre, since a worker is separated from the products of his or her labor, he or she looks for meaning in different aspects of life. The hole he or she feels inside is filled with commodities and entertainment, such as literature, cinema, or sports. The supporter does not have to be athletic, nor is he or she expected to ever participate in any kind of athletic activity. Lefebvre writes that the supporter "participates in the action and plays sports via an intermediary" (2014, p. 58). Professional sports are therefore based on the illusion that the person performing on the field or the court is in some way influenced by the supporter. Simultaneously, with the notion of "play" no longer crucial for the popularity of sports, nor the main motivation behind the participation of professional athletes, it is the supporter who is at the forefront of modern sports and his or her need for satisfactory leisure that is the main reason the game is even played, whether the reason for such satisfaction is the team emerging triumphant from the contest or the experience of an exceptional, highlight-worthy play.

The need for entertainment and the craving for stimulation corresponds with Guy Debord's idea of the society of the spectacle. Debord claims that modern society is an image-driven culture where each public persona - understood as a musician, politician, or athlete - conceals his or her individuality in order to serve the spectacle. The spectacle is the culture of commodities, and thus serving it simply means endorsing various products. Creating content that is appealing to the spectators fuels the spectacle, causing a craving for even more stimulation. Those who serve the spectacle are expected to create more memorable images for society to consume. Reality may be an element of the events crafted according to the needs of the spectators, but it gets lost under the images of and/or attached to the event itself. The society of the spectacle absorbs these images with no regard for reality and is characterized by the need for the mediation of events. Events without such mediation, presented simply as they are, are not appealing enough for consumption. The society of the spectacle craves gripping headlines, stories, and characters that it can root for or against.

Regarding sport, traces of this approach can be found in a study quoted by Andrew Zimbalist (2001, p. 92). Conducted in 1948 by the NCAA, the study revealed that $30 \%$ of those interviewed preferred watching a game at home than in person. This may explain the need for the mediation of sports. As Arthur Raney observed, "overwhelmingly, media consumers report that they view mediated sports because of the emotional rewards they receive from doing so" (2009, p. 340). Unlike Morgan's motivation, the main motivation that media consumers have for watching games is entertainment. The spectacle makes great use of their attention by attaching commodities to games. During a sporting event, everything is "sponsored by" or "brought to you by" a certain company. One notable case is the new replay system introduced by Major League Baseball. 
Samsung's sponsorship of the system goes beyond the company logo appearing before and after revisions of a given play. Umpire assistants are dressed in Samsung attire, the system has been officially renamed Samsung Replay, and beat writers construct stories in a way that allows for writing not only about plays, but replays as well (Gaines 2014). While Samsung's technology enhances the experience of a baseball game and is actually helpful in determining the outcomes of contests, such marketing could be off-putting for a casual sports fan. Instead, since branding is an element of professional sports, the technology is accepted, and even welcome. After all, mediation would not be possible without the media and media devices.

Douglas Kellner argues that sports are "a largely untheorized and underrated aspect of the society of the spectacle." According to Kellner, the sports version of the spectacle is a somewhat "unholy alliance between sports celebrity, commercialism, and media spectacle" (2001, p. 2). Kellner attributes different expectations regarding sports to the change of attitude between the industrial and postindustrial eras. During the first, sports was "an adjunct to labor," useful in implementing the idea of teamwork and keeping workers' bodies fit, strong, and healthy. In the present, postindustrial era, Kellner writes, a spectator sport "requires consumption and passive appropriation of spectacles to reproduce the consumer society" (2001, p. 3). While the former notion corresponds with Morgan's expectations regarding sports, it is the latter that is prevalent today. The break from everyday life that sports were supposed to provide has been replaced with an illusion. In order to be consumed properly, modern sports must instill this illusion in the spectators, while simultaneously not straying from the regular workplace and societal structure known to the workers.

This is only one of a plethora of illusions offered by modern sports. Most of them are concerned with commodities, and one of the objectives of sports entertainment, as with any other facet of capitalism, is to promote, sell, and instill the need for more objects. These objects may be divided into two groups: team merchandise and individual endorsements. By wearing team merchandise, fans express their devotion to a team. Team jerseys are not only reserved for game days; by wearing them outside the arena or stadium, the fan differentiates himself or herself from the rest of society, and when encountering another fan of the same team, both may identify themselves as members of an exclusive club. This, of course, corresponds with the idea of the spectacle, as someone wearing a jersey may not be a devoted fan, but rather a "bandwagoner" someone who wears it in order to improve his or her social position and appear cool. Bandwagoners often change the team they are rooting for depending on which one is more successful or "cool." The NBA's Golden State Warriors are the team that has probably gained the most bandwagon fans in recent years in American sports. Some of them, like Farhad Manjoo, are not even afraid to admit it. Fans who rooted for the team when it was led by Chris Mullin, Latrell Spreewell, or Monta Ellis and were disappointed on an almost yearly basis now have to endure skyrocketing ticket prices and gentrification, as the team owners plan to move the Warriors organization from industrial Oakland to exclusive San Francisco "thanks to bandwagon fans like [Manjoo]" (Manjoo 2016). The team jersey, a game ticket, or a selfie from the game posted on Snapchat instills in the fan the illusion of participation in the team's success, while also projecting this illusion externally. By presenting oneself as a fan of a successful team, one not only has more reasons for satisfactory leisure by celebrating victories, but most of all creates the impression of being successful oneself.

Bandwagon fans may also abandon the team they are rooting for when their favorite player on that team, who by coincidence is often the best, is traded. The two most notable cases of such bandwagoning concern NFL quarterbacks Joe Montana and Peyton Manning. Joe Montana is considered one of the best quarterbacks in NFL history. When he became injured, reserve Steve Young took over the starting role. Young recorded the best passer rating in the NFL in the 1991 season and became league MVP in 1992. The following year, Montana was traded to Kansas City, and in the 1994 season the 49ers and Chiefs met in a regular season game. Instead of rooting for their team, many 49ers fans rooted for Montana and the Chiefs (NFL Films 2006). The devotion that the 49ers fans have for Joe Montana is probably equaled by that of Indianapolis Colts fans for Payton Manning. In Indiana's case, after a season ending in Manning's injury, which resulted in the team having the worst record in the league and winning an eventual first pick in the draft, there was no quarterback controversy, but rather a chance to pick the future franchise player who would become the team quarterback for years to come. Manning joined the Denver Broncos, while rookie Andrew Luck instantly became the starting quarterback for the Colts. Here the departure was mutual, and Manning's number was retired by his 
original team almost immediately, as he retired from the NFL (Andress 2016). When the Colts were eliminated in the 2016 playoffs, fans of the team collectively rooted for the Broncos to win the Super Bowl (Six 2016). Nike and the NFL decided to "cash in" on this by offering fans an official split Colts/Broncos Peyton Manning jersey. ${ }^{1}$

The examples of Montana and Manning mentioned above also illustrate the fact that the very idea of being a supporter of a team is an illusory one. When one makes the claim that they are a Lakers or Yankees supporter, what they are really saying is "I support the business-oriented organization by expressing my loyalty to the organization's brand." Given that a "team" is a living organism with a constantly changing roster, due to players being traded, veterans retiring, and rookies coming into the league, the term "team" is a fluctuating one as no team is the same organism from season to season. One can be a supporter of the Boston Celtics franchise all his or her life due to factors like location, the team's legacy, etc., but when it comes to a team being understood as a collection of players led by a coach, what one is supporting is a temporary phenomenon that can change its form at any given time. Wearing a t-shirt with the Celtics logo on it shows support for the franchise, while wearing Larry Bird's 1986 replica jersey expresses support for the team of 1986 and "Larry Legend" himself.

A player's jersey with his name and number successfully combines team merchandise and individual endorsements. With the appearance of the official Manning split jersey, it seems that the combination may be even more successful, making a profit for not one, but two teams, the league, the player, and of course, Nike. Still, individual endorsements may sometimes differ from league endorsements, causing a conflict of interests between the player and the league or putting players against each other as they try to endorse their products. The latter was the case during a "twitter-war" between Gatorade, Powerade, and Body Armor regarding LeBron James' cramps in Game One of the 2014 NBA Finals. Dehydration forced LeBron out of the final minutes of the game, so Gatorade decided to criticize Powerade, the energy drink endorsed by James. As Gatorade has an exclusive deal with the NBA, it was revealed that LeBron was actually drinking the official energy drink of the league during that game. Body Armor then criticized Gatorade for its hypocrisy, but not without endorsing its own energy drink (Brown 2014). The absurdity of the situation epitomizes the issue that one might have with professional sports. As everyone involved wants to make a profit, issues as delicate as an athlete's health or even life may be used by the sponsors. Instead of objecting to their commodification, athletes gladly participate in the spectacle: in this case, Kobe Bryant used LeBron's injury to endorse the Body Armor energy drink.

The examples above illustrate a certain interrelation between sports events, spectators, the media, and business, resulting in the phenomenon of the sports spectacle. Sports fans, just like other people, desire stories that "enhance" the experience of the otherwise meaningless act of someone playing sports. The most incredible sports play, be it a slam dunk, free kick, or a somersault, has no tangible impact on reality, especially the reality of a spectator. Even a championship-winning goal is meaningless considering the fact that one is only a champion for a limited period of time. As soon as the new season begins, "champions" become "title holders" and new "champions" will emerge at the end of the new season. What makes "champions" memorable and relevant is the narratives that are created around an event. Stories created by the media add the Baudelarian "sign value" 2 to an event: Jordan scoring 35 points is an event; a flu-ridden Jordan scoring 35 points in Game 5 of the 1997 NBA Finals is a heroic act. The narratives create a spectacle in which an individual who runs and jumps for the entertainment of the crowds becomes an idol. What follows is that companies want to cash in on the individual's idol status and turn him or her into a brand and a commodity, thus boosting the sales of their products by making use of the spectacle's illusory significance.

The "unholy alliance" can easily be found in professional sports, but our intention is to look at the spectacle-generated illusions found in academic sports, which traditionally are viewed as a less "tainted"

\footnotetext{
${ }^{1} \mathrm{http}: / /$ www.broncosofficialauthentic.com/nike+peyton+manning+mens+broncoscolts +two +tone+limited + jersey $+18+\mathrm{nf}$ $1+$ denver+broncos

${ }^{2}$ Baudrillard, Jean. 1981. For a Critique of the Political Economy of the Sign. Telos Press Ltd. St. Louis. Print.
} 
version of organized physical activity. This version should be closer to the idea of play, as academic athletes are not (at least not officially) financially compensated for their performances, but rather perform "after school." College sports should therefore be understood as leisure, since students engage in the activity during their free time. This is of course another illusion concerning the sports industry, as academic sports are really not that different from professional sports. In his study of academic sports, Andrew Zimbalist noticed just two differences: college athletes (officially) do not make any money, and the NCAA does not pay taxes "on their millions from TV deals, sponsorships, licensing, or Final Four tickets" (2001, p. 5). In this light, academic sports seem even more illusion-based than their professional counterpart.

\section{Illusions concerning academic sports}

The term "student-athletes" separates the group from both students and athletes. They are not regular students because they generate "hundreds of thousands of dollars for their schools" (Zimbalist 2001, p. 37), and they are not regular athletes because they have to attend classes, simultaneously devoting "from thirty to sixty hours a week to their sport" with the risk of losing their scholarship if they get injured or perform poorly (Zimbalist 2001, p. 37). The term itself was coined in 1953. Since student-athletes were not college-employed, schools were not obliged to cover their health bills, which created a legal loophole that allowed schools to avoid paying insurance claims for injured players. According to Taylor Branch, "that they were highperformance athletes meant they could be forgiven for not meeting the academic standards of their peers; that they were students meant they did not have to be compensated, ever, for anything more than the cost of their studies" (2014). Used at first as a legal defense, the term quickly came to define the special status of collegiate athletes. They were supposed to embody the Greek ideal, mens sana in corpore sano, which positioned them above the average students who were attending university "just" to get a degree. Some scholars, like Billy Hawkins, refrain from using the term "student-athletes" altogether and refer to students participating in athletic competitions simply as professionals (2010, p. 12).

Becoming a student-athlete of course has its benefits. These are enumerated by Zimbalist: "a possible college degree; free tuition, room and board; free, special tutoring; privileged living conditions while in college; various psychological and social benefits, and, for some, payments on the side" (2001, p. 37-38). The biggest problem of the system is not that the best students are not being compensated enough for their contributions on the field or court, as they should make up for it once they leave college. What he means is that once they sign professional contracts, it will definitely be worth the wait, at least from a financial standpoint. His biggest issue is with "athletes [that] are not the top stars and they never make it to the pros. Nor do they produce large revenues for their schools" (2001, p. 52). They are the ones truly exploited by the system, as they devote their time to something that will never be their career instead of studying for a position that they could take on after college. Sports scholarships are of course not equal, as some players make more than others, but most "bottom of the pile" players are not financially compensated for their participation in practices and games. Still, they sacrifice their free time for the sport they love as well as the illusory benefits of being a college celebrity.

At the same time, it is the coaches who turn out to be the true superstars and beneficiaries of NCAA sports programs. They are also very well compensated for their work. This, of course, applies mostly to basketball and football programs, as these two bring in the most revenue for the NCAA and universities. The highest earner for the 2015-2016 season was Duke University's Mike Krzyzewski, whose base salary was \$7.3 million (http://sports.usatoday.com/ncaa/salaries/mens-basketball/coach/\#). The high pay may be attributed to Krzyzewski's tenure - almost 40 years - and success in running the program. However, the second highest earner, John Calipari, made $\$ 6.6$ million, even though he has only been working at the University of Kentucky since 2009. In seven years, Calipari led his team to one championship and four Final Four appearances. His contract is based on his recent success, and its size is supposed to keep the school competitive in Division I basketball. For the sake of comparison, an average player's salary for the 2016-2017 NBA season is projected at almost \$6 million, mostly thanks to the new salary cap boost (http://www.basketballreference.com/contracts/players.html). The two best coaches in Division I make more than the average NBA 
player, while most of their players will never reach that salary playing professional sports. Since the coaches' objective is to win, not to prepare their players for life after college, there is a clear conflict of interests, causing the coaches, even despite their best intentions, to exploit the players they recruit for their teams.

Zimbalist criticizes this approach, which he attributes to the commercialization of school sports programs and the compromising of educational standards in Division I universities (2001, pp. X-xi). Schools do this in order to uphold their status and appease the NCAA. Calipari has been almost notorious for his repeated rule violations, although it might be argued that allowing underdeveloped players to leave for the NBA or forging their SAT scores is actually just succumbing to said players' wishes. Thanks to television contracts and merchandise sales, in 2001 the NCAA was able to afford its own marketing division, real estate subsidiary, and its own Learjet (Zimbalist 2001, p. 4). As millions of dollars are available for the best teams, schools feel inclined to cheat in order to lure the best athletes and keep them at their schools. Zimbalist again points out at what cost this is occurring: "resources are lavished on the recruitment of top athletes, not top scholars. Full financial scholarships go to the best athletes, not the best students" (2001, p. 12).

Even though the author praises Duke for its ability to balance sports programs with the things every university is supposed to do, he uses the school as an example of unequal scholarship distribution: in the 19931994 academic year, 550 student-athletes were awarded $\$ 4$ million, while 5,900 were supposed to share $\$ 400,000$ in merit grants. That season the team was led by Grant Hill and reached the NCAA Final. Christian Laettner, Bobby Hurley, and Hill graduated in 1992, 1993, and 1994, respectively, and the team was left without a player who would lead it to further Final Fours, hence the need for such resources - the team needed to stay competitive. Once Duke successfully recruited a player, he would become its cornerstone for the next four years.

Maintaining a certain competitive level for so long was hard to achieve in the 1990s, but it is even harder in contemporary academic basketball. A rule made effective prior to the 2006 NBA Draft states that athletes need to be 19 years old in order to be eligible for the NBA draft and are no longer allowed to join the league immediately after high school. One of the outcomes of the rule is that it has produced a great amount of "oneand-dones," understood as players who join a university and leave it just a year later to realize their dream of playing in the NBA. Some players, like Brandon Jennings or Emmanuel Mudiay, were so NBA-oriented that they preferred to spend a season playing professional basketball outside the United States instead of attending college for a year. Mudiay claimed he was foregoing college for financial reasons, as he has a family to support, while Jennings wanted to develop himself as a player and not "worry about school and things like that" (Gleeson 2014; Rhoden 2008). Jennings was supposed to attend the University of Arizona. However, once he did poorly on the first standardized test and very well on the second, he was asked for a third take because of the major difference in test scores. As he would leave school after a year anyway, Jennings decided to forgo college and play in Italy instead.

Still, most players prefer to stay in the country and "suffer" through a year in college before joining the league. The need to attend college is enforced by the NBA, while early departures are caused by what Zimbalist describes as "a universal perception among inner-city youth that the only ticket out is sports" (2001, p. 31). To back up his claim, Zimbalist quotes a 1990 study in which $43 \%$ of African American students expressed the belief that they would become professional athletes. According to a 2016 study by the NCAA, the probability of male athletes turning pro in basketball is actually $1.1 \%$ (http://www.ncaa.org/about/resources/research/estimated-probability-competing-professional-athletics). The perception of sports as being a way out of inner-city oppression is another illusion concerning organized sports, which eventually led to what Billy Hawkins refers to as "the New Plantation." According to Hawkins, the system exhibits institutional racism: the NCAA is a predominantly white environment that makes use of African American athletes' labor. Hawkins writes that "race is grounded in ideals of power, privilege, oppression, and exploitation, where White supremacy situates white-skinned people in positions of power and privilege, and as a result, people of color have been oppressed and exploited; oppression and exploitation based on race are forms of racism" (2010, p. 109). The disproportionate percentage of African Americans on university teams and African Americans in universities seems to prove Hawkins' thesis. According to a 2015 
report by Shaun R. Harper, Collin D. Williams Jr., and Horatio W. Blackman, African Americans constitute just $2.8 \%$ of undergraduate students, but $64.3 \%$ of members of basketball teams at six major NCAA Division I athletic conferences (quoted in Harper 2015). The perception may be that African Americans are at universities mostly to generate revenue for schools, which is then redistributed - through better teaching standards, equipment, staff, etc. - to the student body without respect to the very race that was crucial in making this redistribution possible. "One-and-done" athletes are therefore nothing short of hired guns who just help keep the universities rich without reaping the benefits of their labor, as they leave almost immediately after their first season.

On the other hand, Hawkins admits that it is "hard to be critical of racism" when taking into account the opportunities that NCAA sports provide for African American athletes (and white ones as well; 2010, p. 116). Solving the problem with compensation for play would involve changing the organization not only of the NCAA, but of the whole of American society. College sports are nothing more than a market where recruitment is in no way different than during the NFL or the NBA draft. Indeed, athletes are presented with a chance to get a degree, but not at the cost of a decline in on-court and on-field performance. The hours that other students use to study for their classes must be spent by student-athletes practicing or participating in games, leaving little to no time for studying.

When adding to that the pressure to provide for their families, it is not surprising that the athletes want to get that obligatory year of college out of the way and start earning money. This shift in attitude has affected many college programs, but probably none more than Duke University's basketball program. Since taking control of the program in 1980, Krzyzewski has made it his aim to recruit players who will stay at Duke for four years. The first player to leave after his freshman year was Corey Maggette in 1999, and the next one was Luol Deng in 2004 (Balladares 2015). However, the trend of recruits staying longer at Duke continued, and in 2010 a team consisting of three seniors and two juniors won the NCAA championship.

Still, the "plantation" element is highly visible as the academic performance of student-athletes (regardless of their race) is not as vital as their on-court performance - not just to the players and coaching staff, but even more to fans and alumni. Moreover, a Duke player's athletic involvement needs to be consistent. Duke players are criticized when leaving the program too early - they are deemed ungrateful and unworthy of remaining members of the "family." This was the case with Elton Brand, who left Duke after two years. Brand actually wanted to leave college after just one year, but the coach convinced him to stay, which benefited the player and his draft position - he was picked first in the 1999 NBA Draft. Still, when Brand left college a year later than he initially intended, he was met with criticism and received an infamous e-mail from an alumnus who claimed that Brand did not actually belong on the team in the first place since he left so early and would never be part of the "Duke family" (quoted in Wagner 2015). According to Brand, this e-mail signified everything he did not like about the university. It should be noted, however, that what Brand disliked was not racism, but the demanding attitude towards Duke's student-athletes.

\section{Typical Blue Devil - white and privileged?}

The hatred towards Duke stems from the illusion that the school is white, rich, and racist. In a 2005 MSNBC study, Duke received 53\% of the votes for the most hated team in college basketball, while a USA Today poll claimed that $49 \%$ of viewers actively rooted against Duke in the 2010 NCAA Finals (quoted in Tucker and Bagwell). In Dime magazine's ranking of the twenty most hated college players of all time, six were from Duke University (Jefferson 2013). Number one on that list was Christian Laettner. ESPN devoted a documentary to the ever-present hatred of the player two decades after he ended his college career. Laettner is almost synonymous with Duke University's basketball program. On the court, he epitomized the qualities associated with white players: fundamentals, hustle, and hard work. As he was from a blue-collar environment, Laettner's presence at the university should have abolished one stereotype regarding the team: the school may be private, but the best player was not entitled, nor well-off. Actually, only one player from the starting lineup that won the 1991 and 1992 NCAA Championships was from a middle-class family - Grant Hill, who was also African American. 
The documentary Fantastic Lies (2016) shows how Duke's lacrosse team rape accusations cemented the idea of "Duke entitlement," as the players on that team were white and well-established. In the film, all of the speakers underline the special status of the university, one of them calling it "the Harvard of the South." In 2006, an African American stripper accused some members of the team of rape, which immediately conjured up all the stereotypical opinions regarding Duke: white, privileged, and arrogant. The case was about class and race, the issues that needed to be addressed, but as the accusations proved false, it turned out that Duke was the wrong subject for such a discussion. Both Zimbalist and Hawkins practically exclude Duke from their discussion regarding unfair treatment of student-athletes and African American student-athletes respectively, which makes the university absent in any discussions regarding these issues. Still, even now the perception among many fans is that at Duke "all the players are either white or want to be white" (quoted in Smith 2016). The accusations concerning the lacrosse team, the ease with which they were absorbed by society and the media, and the constant illusion that Duke is an all-white school, resulted in the illusion of Duke being a racist institution.

Actually, Duke is well above the national average in racial diversity, with $47.8 \%$ white, $21.1 \%$ Asian, and $9.9 \%$ African American students compromising the three main ethnic groups (http://www.collegefactual.com/colleges/duke-university/student-life/diversity/). But the critique of Duke is not about racism per se, as it is obvious that neither the fans nor faculty are racist. It is more about their way of conduct, which can be considered "white." When Duke fans try to defend their team, they often sound racist. For example, in an article written in defense of Duke, Rob Kirkpatrick writes: "I simply enjoy watching Mike Krzyzewski's team win year after year by playing disciplined, fundamentally strong basketball while avoiding the showboating and individual-over-team play, not to mention the NCAA violations, that often mar the college game" (2011). This excerpt clearly presents the issue that other teams and fans have with Duke. Discipline and fundamentals signify a corporate approach to the game of basketball, while criticism of showboating and individuality show a certain bias towards both. To put things more clearly, it presents a bias against the "black" aspects of basketball, like flashy plays and expressive celebrations.

Krzyzewski himself often teaches others about how the game is supposed to be played. By authoring books like Beyond Basketball: Coach K's Keywords for Success, The Gold Standard: Building a World-Class Team, or Leading with the Heart, he puts himself in the position of authority not only on basketball, but on how to achieve success in life. His reputation as a self-proclaimed leader took a hit when he chastised a player for what can be described as celebrating too vividly. As his team was eliminated from the NCAA Final Four by Oregon, Krzyzewski approached Dillon Brooks of the Ducks and said the player was too good to be "showing off" like that. After the game, Krzyzewski denied that he chastised the player, while the video from the game showed otherwise (Ziller 2016). Consequently, Krzyzewski was declared a sore loser - just like his players, who were reluctant to congratulate Oregon on their success. ${ }^{3}$ A similar situation occurred in 2007 when Krzyzewski criticized a player from Virginia Tech for bumping chests with his teammate and celebrating in front of Duke fans (Petchesky 2016). Actions like these justify Duke hatred and continue to enforce the stereotype of arrogant Duke athletes that started in the 1990s with Christian Laettner.

I Hate Christian Laettner (2015) tries to present and understand how the power forward became one of the most hated players in college basketball history. The implication is that Laettner was hated because he was a white Duke athlete. Laettner was third in the line of big, unathletic white players who were a staple of Duke Basketball. Both Jay Bilas and Danny Ferry paved the way for Laettner and the style of play preferred at that time by Duke's coach. Krzyzewski did not care about flashy plays - Duke Basketball was fundamental basketball. Part of the hate regarding Duke's 1991 and 1992 championship teams may be attributed to a cultural shift and the rising popularity of hip-hop culture. In order to win, Duke had to face teams like UNLV or Michigan, who at that time epitomized what was really "cool." Both teams' starting line-ups were solely

\footnotetext{
${ }^{3}$ A claim could be made that these student-athletes and their coach did not even learn from basketball history, otherwise they would have known what consequences and reputation followed the "Bad Boys" - the Detroit Pistons players who, in 1991, refused to congratulate the Chicago Bulls players after having been eliminated by Jordan and his teammates in the Eastern Conference Finals, leaving no place for Isaiah Thomas on the Dream Team.
} 
African American, while their team leaders, Larry Johnson and Christian Webber, were athletic and boastful. Their plays were quick and eye-catching, while Duke was interested in the basics - hustle and jump-shots. Krzyzewski did not give his players much freedom on the court, as he was interested in wins, not in developing individual talent. He wanted his players to stay at Duke for four years so that they could learn to play his way and achieve more for the university.

Krzyzewski's policy of fundamentals and relatively permanent roster, reflected in Laettner's team of the early 1990s, was the very reason for Duke's success and criticism. "Duke haters" saw arrogance and white privilege in the team and the coach, not seeing the irony that what Krzyzewski was criticized for, other coaches were praised for. Ten years before Krzyzewski's and Laettner's team, Dean Smith, a renowned coach, became the object of "a joke that spread across basketball in the late 1980s: Who was the only person to hold Michael Jordan under 20 points a game? The answer, of course, was Dean Smith" (Lazenby 2014). Just like Krzyzewski, Smith created the basketball program at the University of North Carolina. He emphasized sharing the ball, criticized "flashy" plays, and encouraged players to focus on their education. The difference between Krzyzewski and Smith was that the latter coached at UNC, and instead of "pushing" Laettner onto the Dream Team, he got to hold Jordan under 20 points.

The juxtaposition of the two coaches illustrates the illusory value of objectivity among anti-Duke sports fans blind to the changing realities of Duke's rosters during Krzyzewski's tenure as head coach. It was only during the 1981-1982 season, the coach's second, that the team featured just one African American player in the starting lineup. More often there was a sole white player in the starting line-up - five seasons, including a stretch of four seasons from 2000 to 2004, with the player being either Mike Dunleavy Jr. or J.J. Redick. Most times - eleven in total - there were two African American starters. This includes the 2009-2010 championship team. This may be why Hawkins does not use Duke in his argument about the "New Plantation" - the overrepresentation of African American students in athletic activities is rather an exception to the rule at Duke. Four times the team featured no white starters, while during the 1997-1998 and 1998-1999 seasons they were not even important members of the rotation. The 1998-1999 and 2014-2015 teams won NCAA championships. That last championship team is of special importance, as the 2014-2015 starting line-up did not only feature five African American freshmen, but played in a way that was unlike everything Duke fans - and haters - were used to. Instead of fundamental, team-oriented basketball, their play was based on flash and individual genius.

\section{Concluding remarks}

The world of sports, be it professional, amateur, or questionable (student-athletes) is a world revolving around the money, spectacle, images, signs, and illusions that they create. Duke University's athletic department and its basketball program play according to the rules of the world they operate in. Duke, Krzyzewski, and their basketball players are by nature subject to the mechanism governing organized sports. One of the major mechanisms, we dare say, is fandom and its emotional and culturally conditioned reactions to people, events, and places. Neither the media nor business will simply discard a successful team because fans believe that the team stands for "white privilege," "entitlement," or "arrogance." Business is business: it is cold and calculated; fans are not.

One might claim that Duke's alleged racial bias, seen as such by the fans of other teams, is a result of the time factor and the cultural shift that took place in American culture in the 1990s. Duke's "greatest game" (the NCAA Finals against the University of Kentucky) and the appearance of its most hated player (Laettner) both occurred in 1992, a year that marked the polarization of American culture into whites and blacks. The early 1990s not only witnessed O.J. Simpson's trial and the brutal assault on Rodney King by the L.A. police, two events that heightened racial tensions in American society; they were also a time when the uniquely urban and mostly African American culture of hip-hop began entering the mainstream, bringing with it elements of language, fashion, music, and attitude that had previously been considered counter-culture.

One of Duke's main rival teams of that era, Michigan University, whose starting five were famously dubbed the "Fab Five," represented and even popularized hip-hop culture on the basketball court. The members of the "Fab Five" were inner-city African Americans who listened to rap, played flashy basketball based on 
individual showmanship, and demanded that student-athletes be remunerated for playing college games. Webber, Rose, Howard, and their teammates were vocal, boastful, proud, and popular. Their popularity (and notoriety) placed the "Fab Five" in direct opposition to Krzyzewski and Laettner's "white" Duke team, and the contrast between the two teams reflected the polarization of American culture at the time.

Laettner, who was the face of Duke Basketball, especially found himself in a very complex situation. On the one hand, he embodied Duke's arrogance and entitlement. As Jack McCallum put it, "he seemed tailormade for Duke, a magnet for highly regarded Caucasian players who end up irritating the masses (...) he was just too much a Dukie not to become a Dukie" (2012, p. 1668). By "Dukie," McCallum means white, privileged, and arrogant. Privileged, Laettner was not - white and arrogant, yes. However, given that Laettner came from a "blue-collar" background, his arrogance should not be viewed in terms of "white privilege," but rather as a result of the young athlete's success and adulation among Duke fans. After winning the NCAA championship by hitting a buzzer-beater, Laettner shared the fate of any 20-year-old sports star - popularity went to his head and he grew too big for his boots. On the other hand, Laettner was a member of a team that played a sport that was the domain of African Americans; the culture of the sport of basketball was black. And Laettner, perhaps sensing the cultural shift mentioned above, wanted to be black too:

[Grant] Hill says that the white-bread kid from Nichols School also wanted to be black. "One year Bobby [Hurley] got hurt and Tony Lang was starting for him and Christian's in the huddle clapping his hands and going, 'Okay, we got five brothers starting.' And it didn't seem like he was kidding." (McCallum 2012, p. 1691)

Regardless of whether Laettner was kidding or not, he was a white, dominant player in a sport of black, aspiring players like Webber, who represented an increasingly popular hip-hop culture and whose team had never achieved the level of success as Laettner's Duke. What made matters worse for Laettner's image was the fact that he was selected to be the only collegian on the famed Dream Team over Shaquille O'Neal. O'Neal, a giant (7' ''”), outspoken, and fun-loving player from LSU was, as an individual player, more dominant and more flashy than Laettner. He was also black. Jack McCallum, a renowned sports writer, emphasizes that "while O'Neal would've been more fun, a genial giant of a target for the good-natured slings and arrows released from the quivers of Jordan and Barkley, Laettner was the right choice for the body of work that he had shown in four years" (McCallum 2012, p. 1881). Nevertheless, the selection of Laettner and the fact that "his college coach, Mike Krzyzewski, a committee member, pushed that idea" (McCallum 2012, p. 1642) cemented the illusory image of Laettner as white and privileged. In the context of the polarized American culture of early 1990s, Laettner had to be hated by default - and with him, Krzyzewski and Duke.

As is presented above, there is no "real" reason to view Duke Basketball as white, racist, privileged, or arrogant. And yet, this is still the image of the Dukies. Naturally, this image remains in the eyes of college basketball fans who are not Duke fans. As we mentioned above, sports fans are loyal to home teams rather than facts. Twenty-five years after Laettner became the embodiment of a "Blue Devil," with Krzyzewski still the head coach of the Duke basketball team and having won five NCAA championships since 1991 with a diverse roster of players, it seems that the hatred that Duke still faces is simply a matter of tradition based on illusion.

\section{REFERENCES}

Andress, S. (2016, March 20). Peyton Manning reflects on Andrew Luck and reunion with Colts. Indianapolis Colts Official Website. Retrieved June 6, 2017, from http://www.colts.com/news/article-1/Peyton-Manning-Reflects-onAndrew-Luck--Reunion-with-Colts/

Balladares, A. (2015, June 4). Duke Basketball: A change in Coach K. iSportsWeb. Retrieved June 6, 2017, from http://isportsweb.com/2015/06/04/duke-basketball-a-change-in-coach-k/

Baudrillard, J. (1981). For a Critique of the Political Economy of the Sign. St. Louis: Telos Press Ltd.

Blanchard, K. (1995). The Anthropology of Sport: An Introduction (A Revised Edition) (Kindle edition). London: Bergin \& Garvey.

Branch, T. (2014, February 20). How the myth of the NCAA "student-athlete" was born. Deadspin. Retrieved June 5, 2017, from http://deadspin.com/how-the-myth-of-the-ncaa-student-athlete-was-born-1524282374 
Brown, L. (2014, June 6). Kobe Bryant uses LeBron's cramps to plug his Body Armor sports drink. Larry Brown Sports. Retrieved June 4, 2017, from http://larrybrownsports.com/basketball/kobe-bryant-lebron-cramps-body-armor-sportsdrink/231684

deBruyn, J. (2015, September 9). For low-income students, Duke ranks as $7^{\text {th }}$ cheapest private university. Triangle Business Journal. Retrieved June 6, 2017, from http://www.bizjournals.com/triangle/news/2015/09/15/duke-universitypropublica-cheap-low-income-pell.html

Gaines, C. (2014, September 2). MLB's replay system is now a huge money-maker for the owners. Business Insider. Retrieved June 6, 2017, from http://www.businessinsider.com/mlbs-expanded-replay-system-samsung-2014-8?IR=T

Gleeson, S. (2014, July 14). Emmanuel Mudiay decides not to attend SMU, will turn pro overseas. USA Today. Retrieved June 4, 2017, from http://www.usatoday.com/story/sports/ncaab/2014/07/14/emmanuel-mudiay-smu-decides-to-turnpro-overseas/12634877/

Harper, S. R. (2015, November 11). Black college football and basketball players are the most powerful people of color on campus. The Washington Post. Retrieved June 4, 2017, from https://www.washingtonpost.com/posteverything/wp/2015/11/11/black-college-football-and-basketball-players-are-themost-powerful-people-of-color-on-campus/?utm term $=.09 \mathrm{bb} 0 \mathrm{c} 7 \mathrm{~d} 889 \mathrm{e}$

Jefferson, B. (2013, August 15). The 20 most hated college basketball players of all time. Dime Magazine. UPROXX. Retrieved June 4, 2017, from http://uproxx.com/dimemag/the-20-most-hated-college-basketball-players-of-all-time/

Karpf, R. (2015). 30 For 30: I Hate Christian Laettner [Motion Picture]. USA: ESPN.

Kirkpatrick, R. (2011, March 23). The racial biases of Duke hating. The Huffington Post. Retrieved June 4, 2017, from http://www.huffingtonpost.com/rob-kirkpatrick/the-racial-biases-of-duke-hating_b_839560.html

Lazenby, R. (2014). Michael Jordan: The Life (Kindle edition). Boston, MA: Little, Brown and Company.

Lefebvre, H. (2014). The Critique of Everyday Life. London: Verso.

Manjoo, F. (2016, June 8). Warriors, tech's team, are soaring out of reach. The New York Times. Retrieved June 4, 2017, from http:/www.nytimes.com/2016/06/09/technology/warriors-techs-team-are-soaring-out-of-reach.html?_r=0

McCallum, J. (2012). Dream Team: How Michael, Magic, Larry, Charles, and the Greatest Team of All Time Conquered the World and Changed the Game of Basketball Forever (Kindle edition). New York, NY: Ballantine Books.

Kallas, H. and Plaut, D. (1995). America's Game: The Super Bowl Champions. San Francisco 49ers - 1994. [Motion Picture] USA: NFL Films.Petchesky, B. (2016, March 29). Coach K has pulled this "you're too good to celebrate" shit before. Deadspin. Retrieved June 6, 2017, from http://deadspin.com/coach-k-has-pulled-this-youre-too-good-tocelebrate-s-1767711424

Raney, A. A. (2009). Why we watch and enjoy mediated sports. In A. A. Raney \& J. Bryant (Eds.), Handbook of Sports and Media (pp. 339-357). Taylor \& Francis e-Library.

Rhodes, W. C. (2008, June 26). Old world lesson for the new N.B.A. The New York Times. Retrieved June 4, 2017, from http://www.nytimes.com/2008/06/23/sports/basketball/23rhoden.html?_r=1\&em\&ex=1214366400\&en=a89b992b0e69 2eff\&ei $=5087 \% 0 \mathrm{~A}$

Six, A. (2016, January 30). One more for a son of Indianapolis. MMQB. Sports Illustrated. Retrieved June 6, 2017, from http://mmqb.si.com/mmqb/2016/01/30/themmqb-voice-fan-colts-peyton-manning-broncos-super-bowl-50

Smith, C. (2016, March 29). Duke hoops signee Javin DeLaurier offers perfect response to racist anti-Duke tweet. USA Today. Retrieved from http://usatodayhss.com/2016/duke-hoops-signee-javin-delaurier-offers-perfect-response-to$\underline{\text { racist-anti-duke-tweet }}$

Tucker, R. \& Bagwell, A. (2012). Duke Sucks: A Completely Evenhanded, Unbiased Investigation into the Most Evil Team on Planet Earth. New York, NY: St. Martin's Griffin.

Wagner, K. (2015, April 7). Remember when a Duke alum wrote this very bad letter to Elton Brand? Deadspin. Retrieved June 6, 2017, from http://deadspin.com/remember-when-a-duke-alum-wrote-this-very-bad-letter-to-1696196818

Zenovich, M. (2016). 30 for 30: Fantastic Lies [Motion Picture]. USA: ESPN.

Ziller, T. (2016, March 28). Mike Krzyzewski and John Calipari are hypocrites in completely different ways. SB Nation. Retrieved June 3, 2017, from http://www.sbnation.com/2016/3/28/11317118/coach-k-mike-krzyzewski-john-calipari$\underline{\text { hypocrites }}$ 
AUTHOR'S ADDRESS: Tomasz Jacheć

UniversityWarmia i Mazury

Kurta Obitza 1

10-725 Olsztyn

Poland

E-mail: tomasz.jachec@uwm.edu.pl

Received: 4 June 2017; Accepted: 17 July 2017 